\title{
PENGARUH PELATIHAN DAN PEMBERDAYAAN TERHADAP KOMPETENSI DAN KINERJA GURU DI UPTD-PK DEWANTARA
}

\author{
Suraida Fitri, A. Hadi Arifin, Yanita \\ PPIM Universitas Malikussaleh, Lhokseumawe
}

\begin{abstract}
This study aims to examine the effect of training and empowerment of the competence and performance of teachers in UPTD-PK Dewantara. The data used in this research are as many as 152 teachers in SMA Negeri 1 Dewantara, SMA Negeri 2 Dewantara and SMK Negeri 1 Dewantara. The analysis tool used is Structural Equation Modeling (SEM) using AMOS-20 (Analysis of Moment Structure). The results showed that training and empowerment have a significant influence on competence. Training, empowerment and competence have a significant effect on performance. Competence mediates in full mediation the effect of training on performance. Competence mediates partially mediation in the effect of empowering performance.
\end{abstract}

Keywords: Training, Empowerment, Competence, Performance.

\section{PENDAHULUAN}

Sumber daya manusia yang berkualitas mempersyaratkan adanya ketersediaan tenaga pendidik yang handal. Tenaga pendidik yang handal dalam hal ini guru, dapat diperoleh melalui program pelatihan dan pemberdayaan. Pelatihan dan pemberdayaan guru merupakan faktor yang mendorong tercapainya kompetensi guru sehingga dapat memberikan kinerja terbaik bagi organisasi. Organisasi perlu mengidentifikasi kebutuhan guru sehingga organisasi dapat menerapkan jenis program pelatihan dan pemberdayaan yang akan diberikan kepada individu dalam organisasi. Kesesuaian kebutuhan organisasi dan tugas dengan program pelatihan dan pemberdayaan guru akan mendukung peningkatan kompetensi guru.

Menyelaraskan kompetensi guru terhadap perkembangan teknologi dan perkembangan regulasi dalam dunia pendidikan merupakan sasaran dari pelatihan dan pemberdayaan guru, sehingga guru kompeten dalam menjalankan tugas-tugasnya. Tujuan peningkatan kompetensi itu sendiri adalah untuk mengetahui tingkat kinerja yang diharapkan oleh organisasi dari gurunya. Kompetensi guru merupakan sebuah karakteristik dasar seseorang. Cara berpikir, bersikap dan bertindak seorang guru mencerminkan kompetensi guru tersebut. Karakteristik tersebut dapat dipertahankan oleh seseorang pada waktu periode tertentu sehingga guru tersebut dianggap kompeten. Dengan adanya kompetensi maka guru akan lebih memiliki kinerja yang optimal dalam melakukan kegiatan pembelajaran kepada peserta didiknya. 
Definisi kinerja itu sendiri menurut Torang (2012) adalah sebagai kuantitas atau kualitas hasil kerja individu atau sekelompok di dalam organisasi dalam melaksanakan tugas pokok dan fungsi yang berpedoman pada norma, standar oprasional prosedur kiteria dan ukuran yang telah ditetapkan atau yang berlaku dalam organisasi. Keban (2004:67; dalam Rapareni, 2013) berpendapat bahwa faktor pengetahuan, keterampilan dan kemampuan sangat diperlukan untuk mendukung suatu kinerja. Pengetahuan, keterampilan dan kemampuan merupakan kompetensi yang bersifat superfisial, yaitu karakter mendasar dari seseorang untuk mampu menunjukkan kinerja yang efektif atau superior di dalam pekerjaan dan tugasnya.

Sementara itu, kompetensi menurut Zwell dalam Wibowo (2007) menyatakan bahwa kompetensi bukan merupakan kemampuan yang tidak dapat dipengaruhi. Ada beberapa faktor yang dapat mempengaruhi kompetensi, diantaranya sesuai dengan pendapat Gomes (2003) yang mengatakan bahwa melalui training (pelatihan) para pegawai akan menjadi terampil, dan karenanya akan lebih produktif. Selanjuntya Mangkunegara (2007) menyatakan bahwa kompetensi merupakan faktor mendasar yang dimiliki seseorang yang mempunyai kemampuan lebih, yang membuatnya berbeda dengan seseorang yang mempunyai kemampuan rata-rata.

Sejalan dengan pendapat Gomes (2003), pelatihan sangat diperlukan untuk meningkatkan kompetensi seseorang. Moekijat (2006) menjelaskan bahwa pelatihan diperlukan untuk membantu pegawai menambah kecakapan dan pengetahuan yang berhubungan erat dengan pekerjaan dimana pegawai tersebut bekerja. Terdapat tiga syarat yang harus dipenuhi yang menjadi indikator dari pelatihan agar suatu kegiatan dapat disebut latihan: latihan harus membantu pegawai menambah kemampuannya, latihan harus menimbulkan perubahan dalam kebiasaan, dalam informasi, dan pengetahuan yang ia terapkan dalam pekerjaannya sehari-hari, dan latihan harus berhubungan dengan pekerjaan tertentu yang sedang dilaksanakan ataupun pekerjaan yang akan diberikan pada masa yang akan datang.

Selain dari pelatihan, pemberdayaan (empowerment) juga merupakan salah satu faktor yang dapat mempengaruhi kinerja dan kompetensi seseorang. Menurut Luthans (2006) definisi dari pemberdayaan (empowerment) itu sendiri adalah wewenang untuk membuat keputusan dalam suatu area kegiatan operasi tertentu tanpa harus memperoleh pengesahan orang lain. Selanjutnya menurut Judge dalam Pujisari (2001) mengatakan bahwa pemberdayaan selain berpengaruh terhadap peningkatan kinerja, juga dapat menyebabkan karyawan memiliki keinginan untuk mengakhiri tugas atau meninggalkan organisasi.

Program pelatihan dan pemberdayaan guru dapat meningkatkan ketrampilan, pengetahuan dan pengalaman guru terhadap pekerjaannya. Demikian juga halnya dengan Unit Pelaksana Teknis Dinas Pendidikan Kecamatan Dewantara (UPTD-PK Dewantara). Kegiatan dalam pelatihan yang dilakukan oleh UPTD-PK Dewantara bertujuan untuk meningkatkan pengetahuan, keahlian dan kompetensi. Kegiatan pelatihan dilakukan melalui kegiatan pengajaran, pendidikan dan pelatihan yang meliputi materi ilmu pengetahuan, ketrampilan dan keahlian. Kegiatan dalam pemberdayaan guru bertujuan untuk mempersiapkan guru agar dapat menyesuaikan diri terhadap kegiatan mengajarnya. Pengembangan guru memberi kesempatan kepada guru untuk bersosialisasi terhadap tugas dan 
lingkungan pekerjaannya, dengan demikian program pelatihan dan pengembangan memberi peluang terhadap guru agar dapat berperan dalam institusi khususnya pada UPTD-PK Dewantara.

Dapat dijelaskan bahwa penelitian ini bertujuan untuk menguji kembali secara empiris penelitian yang telah dilakukan oleh peneliti terdahulu. Penelitian tersebut diantaranya adalah penelitian yang dilakukan oleh Pravianti (2017) menemukan bahwa secara simultan dan parsial kompetensi dan pemberdayaan berpengaruh positif terhadap kinerja. Selanjutnya penelitian dari Chen (2011) yang juga menemukan bahwa pemberdayaan sangat mempengaruhi kinerja karyawan. selain dari dua penelitian tersebut, Salmah (2012) dalam penelitiannya juga menemukan bahwa pelatihan dan pengembangan karyawan berpengaruh secara signifikan terhadap kompetensi karyawan. Hasil penelitian tersebut diperkuat lagi dengan penelitian dari Suharnomo (2013) yang menemukan bahwa pembinaan, pelatihan dan pengembangan, pemberdayaan dan partisipasi mempengaruhi kinerja karyawan.

Berdasarkan hasil survei awal yang peneliti lakukan terhadap guru di UPTD-PK Dewantara, peneliti menemukan permasalahan yang terkait dengan pelatihan, pemberdayaan, kompetensi dan kinerja guru di UPTD-PK Dewantara. Permasalahan tersebut sangat menarik untuk dikembangkan lebih lanjut dalam upaya untuk meningkatkan kompetensi dan kinerja guru di UPTD-PK Dewantara.

Fenomena yang terkait dengan kinerja guru di UPTD-PK Dewantara, peneliti menemukan dimana kinerja guru di UPTD-PK Dewantara sudah mulai bagus dimana dari segi kuantitas output yang dihasilkan sudah terpenuhi meskipun beberapa guru belum dapat memenuhinya. Dari segi kualitas outputnya juga sudah sesuai dengan SOP yang ditetapkan, walaupun beberapa guru masih perlu perbaikan, perbaikan agar sesuai dengan SOP. Pada umumnya kehadiran sudah dapat dipenuhi oleh guru hanya beberapa yang hadir tidak tepat waktu dengan alasan yang kurang tepat.

Fenomena terkait dengan kompetensi guru di UPTD-PK Dewantara bahwa secara umum ketrampilan untuk menjalankan tugas sudah baik. Dimana masih ada beberapa guru yang mengajar belum sesuai dengan kurikulum, belum dapat menyelesaikan tugas-tugas lain yang diembankan kepadanya, kurang dapat mengambil tindakan yang cepat dan tepat bila ada masalah dengan para siswa atau dengan para guru, kurang dapat bekerja sama untuk menciptakan kenyamanan di lingkungan sekolah dan kurang dapat beradaptasi dengan lingkungan sekolah yang baru.

Terkait dengan pelatihan guru di UPTD-PK Dewantara peneliti menemukan bahwa materi pelatihan yang diberikan belum seluruhnya dapat meningkatkan kompetensi guru, metode pelatihan yang diberikan belum semua yang tepat sesuai yang dibutuhkan, instruktur masih ada yang memberikan pelatihan kurang sesuai dengan materi dan metode mengajar yang tepat, guru jarang mendapatkan pelatihan dan pelatihan yang diberikan kurang berdampak positif terhadap kinerja guru di UPTD-PK Dewantara.

Pemberdayaan guru di UPTD-PK Dewantara diberikan kepada para guru dengan tujuan untuk meningkatkan kinerja mereka. Namun masih ditemukan permasalahan bahwa profesi guru yang mereka emban sekarang ada yang belum sesuai dengan bakat dan minat mereka sendiri sehingga tidak dapat mengeluarkan keyakinan dan kemampuan dari semua potensi mengajar yang mereka miliki dengan baik. Hal ini diketahui dari masih ditemukannya guru yang kurang mampu mentransfer ilmu yang mereka miliki kepada para siswa secara tepat, sehingga tidak memberikan peningkatan yang signifikan terhadap kecerdasan para siswa. 
Berdasarkan penjelasan di atas peneliti mencoba untuk meneliti tentang "Pengaruh Pelatihan dan Pemberdayaan terhadap Kompetensi dan Kinerja Guru di UPTD-PK Dewantara”.

\section{METODE}

Objek yang digunakan pada penelitian ini adalah guru SMA Negeri 1 Dewantara, guru SMA Negeri 2 Dewantara dan guru SMK Negeri 1 Dewantara. Lokasi penelitian yang dipilih adalah UPTD-PK Dewantara yang berlokasi di Jalan Kesehatan nomor 10 Krueng Geukueh Kecamatan Dewantara Kabupaten Aceh Utara.

Populasi dalam penelitian ini adalah guru di UPTD-PK Dewantara yang terdiri dari guru SMA Negeri 1 Dewantara, guru SMA 2 Negeri Dewantara dan guru SMK Negeri 1 Dewantara yang berjumlah 152 orang guru.

Untuk penentuan jumlah sampel dalam penelitian ini juga mempertimbangkan model penelitian yang digunakan. Model penelitian yang digunakan dalam penelitian ini adalah model Structural Equation Modelling (SEM), dimana dalam SEM jumlah sampel yang ideal antara 100-200 (Hair et al., 2009) dan juga harus mempertimbangkan jumlah indikator yang ada dalam model.

Hair et al. (2009) lebih lanjut mengatakan untuk penentuan jumlah sampel dapat berjumlah 5-10 dari jumlah indikator. Dalam penelitian ini terdapat 19 indikator sehingga jumlah sampel bisa berkisar antara 95-190 responden. Jumlah sampel ditentukan dengan mengalikan jumlah indikator dengan 8, sehingga total sampel sebanyak 19 × $8=152$ responden. Sampel diambil dengan menggunakan teknik sampling jenuh. Menurut Sugiyono (2011) sampling jenuh adalah teknik penentuan sampel bila semua anggota populasi digunakan sebagai sampel. Hal ini sering dilakukan bila jumlah populasi relatif kecil.

Teknik pengumpulan data dilakukan dengan memberikan daftar pertanyaan atau kuesioner secara langsung kepada 152 responden yang merupakan guru di UPTD-PK Dewantara yang dibuat dengan menggunakan skala 1-5 (likert) untuk mendapatkan data yang bersifat interval dan diberi nilai atau skor, untuk kategori pernyataan dengan jawaban sangat tidak setuju dengan nilai 1 (satu) sampai dengan sangat setuju dengan nilai 5 (lima).

Bentuk diagram alur full model dengan variabel mediasi penelitian ini adalah seperti pada Gambar 1 berikut ini: 


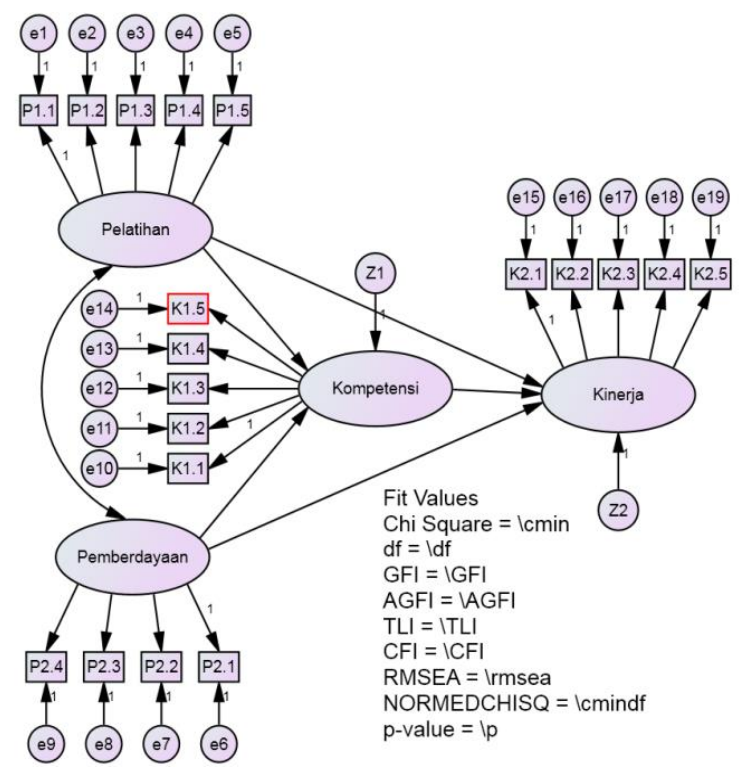

Gambar 1. Full Model Penelitian

Sumber: Dikembangkan Dalam Penelitian Ini

Setelah teori atau model teoritis dikembangkan dan digambarkan dalam sebuah diagram alur, peneliti dapat mulai mengkonversi spesifikasi model tersebut ke dalam rangkaian persamaan. Persamaan ini dirumuskan untuk menyatakan hubungan kausalitas antar berbagai konstruk, dengan rumus seperti di bawah ini:

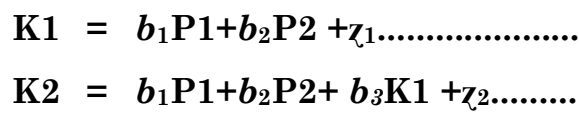

Keterangan:

$$
\begin{array}{ll}
\mathrm{P} 1 & =\text { Pelatihan } \\
\mathrm{P} 2 & =\text { Pemberdayaan } \\
\mathrm{K} 1 & =\text { Kompetensi } \\
\mathrm{K} 2 & =\text { Kinerja } \\
\mathrm{b} 1, \mathrm{~b} 2, \mathrm{~b} 3 & =\text { Koefisien Estimasi } \\
\mathrm{Z}_{1}-\mathrm{Z}_{2} & =\text { error term (residual) }
\end{array}
$$

Menginterprestasikan model dan memodifikasikan model dilakukan bagi model yang tidak memenuhi syarat pengujian yang dilakukan. Untuk langkah ini model yang sedang dikembangkan dan diinterprestasikan dan apabila model yang tidak memenuhi kriteria maka dilakukan modifikasi. Perlunya melakukan modifikasi terhadap sebuah model dapat dilihat dari jumlah residual yang dihasilkan model tersebut. Setelah model diestimasi, residualnya haruslah kecil atau mendekati nol dan distribusi frekuensi dari kovarians residual harus bersifat simetrik hal ini sesuai dengan pendapat Tabachnick dan Fidell tahun 1996 dalam Ferdinand (2014). Bila jumlah residual lebih besar dari 5 
persen dari semua residual kovarians yang dihasilkan oleh model, maka sebuah modifikasi mulai perlu dipertimbangkan selanjutnya apabila ditemukan bahwa nilai residual yang dihasilkan model itu cukup besar (> 2.58), maka cara lain dalam memodifikasi adalah dengan mempertimbangkan untuk menambah sebuah alur baru terhadap model yang diestimasi tersebut. Modifikasi dapat dilakukan dengan menggunakan bantuan indeks modifikasi.

Pengujian hipotesis mediasi dilakukan dengan prosedur uji Sobel (Sobel Test) (Baron \& Kenny, 1986; dalam Preacher \& Hayes, 2010).

\section{KARAKTERISTIK RESPONDEN}

Data penelitian diperoleh dari kuesioner yang telah disebarkan kepada personel Polres Bireuen. Berdasarkan data tersebut diperoleh karakteristik responden dari beberapa kategori, yaitu responden berdasarkan jenis kelamin, umur, pendidikan terakhir dan masa kerja. Tujuan diuraikannya tentang karakteristik responden adalah untuk mengetahui kriteria dari sampel yang telah dipilih menjadi responden dalam penelitian ini, dengan mengetahui tentang kriteria sampel setidak-tidaknya sangat membantu peneliti dalam menghubungkan antara jawaban responden dengan karakteristiknya masingmasing dan ini sangat membantu dalam menginterpretasikan hasil penelitian di bagian pembahasan.

Penggolongan yang pertama adalah penggolongan responden berdasarkan usia. dapat dijelaskan bahwa jumlah responden laki-laki sebanyak 68 orang atau $45 \%$ dari total sampel dan jumlah responden perempuan sebanyak 84 orang atau 55\% dari total sampel. Berdasarkan data tersebut dapat dilihat bahwa guru perempuan lebih banyak dibandingkan guru laki-laki. Hal ini disebabkan oleh adanya kecenderungan bahwa perempuan lebih menyukai bekerja sebagai guru dibandingkan laki-laki. Sehingga guru di UPTD-PK Dewantara lebih dominan perempuan.

Penggolongan yang selanjutnya adalah penggolongan responden berdasarkan jenis kelamin responden. Dapat dijelaskan bahwa sampel penelitian ini didominasi oleh responden dengan umur 31-40 tahun yaitu sebanyak 64 orang atau 42\% dari total sampel. Responden yang berumur 41-50 tahun yaitu sebanyak 44 orang atau 29\% dari total sampel. Responden yang berumur $<30$ tahun yaitu sebanyak 21 orang atau 14\% dari total sampel. Dan responden yang paling terkecil berdasarkan umur yaitu responden yang berumur $>50$ tahun yaitu sebanyak 23 orang atau $15 \%$ dari total sampel.

Dari karakteristik responden berdasarkan umur terlihat bahwa responden dengan usia 31-40 tahun mendominasi guru SMA Negeri 1 Dewantara, guru SMA Negeri 2 Dewantara dan guru SMK Negeri 1 Dewantara, sehingga dari dominasi tersebut dapat peneliti simpulkan bahwa rata-rata guru SMA Negeri 1 Dewantara, guru SMA Negeri 2 Dewantara dan guru SMK Negeri 1 Dewantara masih dalam kondisi yang sangat produktif dan energik untuk dapat memberikan pengajaran kepada para siswa di UPTD-PK Dewantara, karena mengajar juga profesi yang cukup banyak menyita pikiran dan tenaga dari para guru agar dapat menjadi lebih profesional dalam kegiatan belajar mengajar di kelas.

Penggolongan yang selanjutnya adalah penggolongan responden berdasarkan pendidikan terakhir, dapat dijelaskan bahwa sampel penelitian ini didominasi oleh responden dengan tingkat pendidikan Sarjana (S1) yaitu sebanyak 123 orang atau 81\% dari total sampel. Responden yang berpendidikan Diploma (D1-D3) yaitu sebanyak 21 orang atau 14\% dari total sampel. Dan responden yang paling 
terkecil berdasarkan tingkat pendidikan yaitu responden yang berpendidikan Magister (S2) yaitu sebanyak 8 orang atau $5 \%$ dari total sampel.

Hal ini memperlihatkan bahwa guru di UPTD-PK Dewantara didominasi oleh guru yang berpendidikan Sarjana (S1). Hal ini sejalan dengan program pemerintah yang mengharuskan guru minimal mempunyai jenjang pendidikan Sarjana (S1). Dapat dijelaskan juga bahwa guru di UPTD-PK Dewantara memiliki pegawai yang berpendidikan D3, namun mereka bertugas pada bagian tata usaha. Kemudian guru yang memiliki jenjang pendidikan Magister (S2) dirasa masih minim karena hanya berjumlah 8 orang saja. Meskipun demikian, guru SMA Negeri 1 Dewantara, guru SMA Negeri 2 Dewantara dan guru SMK Negeri 1 Dewantara telah didominasi oleh guru dengan tingkat pendidikan Sarjana (S1). Hal ini sudah sesuai dengan peraturan yang ditetapkan oleh pemerintah, yakni guru harus memiliki jenjang pendidikan minimal Sarjana (S1).

Penggolongan berikutnya adalah penggolongan responden berdasarkan masa kerja. Dapat dijelaskan bahwa sampel penelitian ini didominasi oleh responden dengan masa kerja 6-10 tahun yaitu sebanyak 63 orang atau $42 \%$ dari total sampel. Selanjutnya responden yang masa kerjanya 1-5 tahun yaitu sebanyak 32 orang atau 21\% dari total sampel. Responden yang masa kerjanya 11-15 tahun yaitu sebanyak 31 orang atau $\quad 20 \%$ dari total sampel. Dan responden yang paling terkecil berdasarkan masa kerja yaitu responden yang masa kerja $>15$ tahun yaitu sebanyak 26 orang atau $17 \%$ dari total sampel.

Dari karakteristik guru berdasarkan masa kerja tersebut terlihat bahwa responden dengan masa kerja 6-10 tahun mendominasi guru di UPTD-PK Dewantara. Hal tersebut mengisyaratkan bahwa guru SMA Negeri 1 Dewantara, guru SMA Negeri 2 Dewantara dan guru SMK Negeri 1 Dewantara telah memiliki cukup pengalaman dalam mengajar. Selain itu, masa kerja yang lama juga mengindikasikan bahwa guru SMA Negeri 1 Dewantara, guru SMA Negeri 2 Dewantara dan guru SMK Negeri 1 Dewantara memiliki kompetensi yang cukup dalam bekerja. Sehingga dengan pengalaman kerja dan kompetensi yang guru guru SMA Negeri 1 Dewantara, guru SMA Negeri 2 Dewantara dan guru SMK Negeri 1 Dewantara miliki diharapkan mampu menunjang kinerja guru itu sendiri.

Berdasarkan uraian karakteristik responden yang telah peneliti uraikan tersebut maka dapat dibuat kesimpulan secara umum bahwa guru SMA Negeri 1 Dewantara, guru SMA Negeri 2 Dewantara dan guru SMK Negeri 1 Dewantara didominasi oleh guru yang berjenis kelamin perempuan, berusia berkisar antara 31-40 tahun, tingkat pendidikan Sarjana (S1) dengan masa kerja $\leq$ 6-10 tahun.

\section{DESKRIPTIF VARIABEL PENELITIAN}

Analisis deskriptif statistik terhadap jawaban responden bertujuan untuk mengetahui nilai minimum dan maksimum serta rata-rata (mean) dari jawaban responden. Dengan mengetahui nilai ratarata dari jawaban responden maka peneliti dapat mengambil kesimpulan secara deskriptif statistic tentang arah jawaban responden terhadap suatu pernyataan dalam kuesioner yang telah ditetapkan.

Menurut hasil perhitungan dengan menggunakan SPSS, dapat dijelaskan bahwa nilai rata-rata (mean) jawaban responden tentang variabel pelatihan sebesar 3,849 atau dibulatkan menjadi 4. Apabila dihubungkan dengan skala yang ditentukan dalam penelitian ini yaitu: (1) sangat tidak setuju, (2) tidak setuju, (3) netral, (4) setuju, (5) sangat setuju, maka kategori jawaban responden secara rata-rata berada 
pada skala 4 atau pada kondisi setuju. Nilai standar deviasi sebesar 0,750 menunjukkan bahwa sebaran data sudah baik karena nilai tersebut tidak melebihi tiga kali nilai mean.

Hal ini berarti secara umum guru di UPTD-PK Dewantara memiliki pelatihan yang baik. Hal ini terlihat dari: materi pelatihan yang diberikan mampu meningkatkan kompetensi guru, metode pelatihan yang diberikan sangat tepat sesuai yang dibutuhkan, instruktur memberikan pelatihan sesuai dengan materi dan metode mengajar yang tepat, guru sering mendapatkan pelatihan dan pelatihan memberikan dampak yang positif terhadap kinerja guru. Pelatihan yang baik ini tentu saja dapat menambah kompetensi guru di UPTD-PK Dewantara dalam bekerja, sehingga kinerjanya akan ikut meningkat seiring dengan meningkatnya pelatihan dan kompetensi guru itu sendiri.

Dapat dijelaskan bahwa nilai rata-rata mean jawaban responden tentang variabel pemberdayaan sebesar 3,808 atau dibulatkan menjadi 4. Apabila dihubungkan dengan skala yang ditentukan dalam penelitian ini yaitu: (1) sangat tidak setuju, (2) tidak setuju, (3) netral, (4) setuju, (5) sangat setuju, maka kategori jawaban responden secara rata-rata berada pada skala (4) atau pada kondisi setuju, hal ini berarti secara umum responden berpendapat setuju terhadap pernyataan dalam kuesioner mengenai pemberdayaan. Nilai standar deviasi sebesar 0,793 menunjukkan bahwa sebaran data sudah baik karena nilai tersebut tidak melebihi tiga kali nilai mean.

Dengan kata lain pemberdayaan guru di UPTD-PK Dewantara sudah baik. Ini mengindikasikan bahwa pemberdayaan guru sudah mampu mendukung kompetensi dan kinerja mereka dalam mengemban tugas sebagai seorang pendidik. Pemberdayaan guru di UPTD-PK Dewantara yang baik tersebut terlihat dari: profesi guru sesuai dengan minat dan bakat yang mereka miliki, guru dapat mengeluarkan semua potensi mengajar yang mereka miliki dengan baik, metode mengajar yang saya terapkan sudah tepat dan guru dapat meningkatkan kecerdasan siswanya. Indikator-indikator tersebut terbukti secara nyata memberikan dampak yang positif terhadap peningkatan pemberdayaan guru di UPTD-PK Dewantara.

Dapat dijelaskan bahwa nilai rata-rata (mean) jawaban responden tentang variabel kompetensi sebesar 3,738. Apabila dihubungkan dengan skala yang ditentukan dalam penelitian ini yaitu: (1) sangat tidak setuju, (2) tidak setuju, (3) netral, (4) setuju, (5) sangat setuju, maka kategori jawaban responden secara rata-rata berada pada skala (4) atau pada kondisi setuju, dengan nilai standar deviasi sebesar 0,784 menunjukkan bahwa sebaran data sudah baik, karena nilai tersebut tidak melebihi tiga kali nilai mean.

Hal ini berarti secara umum guru di UPTD-PK Dewantara memiliki kompetensi yang tinggi karena didukung pemberdayaan dan pelatihan yang baik. Menurut peneliti kompetensi guru di UPTDPK Dewantara dapat ditingkatkan lagi dengan cara: guru dapat mengajar sesuai dengan kurikulum, guru dapat mengajar dan menyelesaikan tugas-tugas lain yang diembankan kepadanya, guru dapat mengambil tindakan yang cepat dan tepat bila ada masalah dengan para siswa atau dengan para guru yang lain, guru dapat bekerja sama untuk menciptakan kenyamanan di lingkungan sekolah dan guru dapat beradaptasi dengan lingkungan sekolah yang baru. Dengan cara-cara tersebut diharapkan kompetensi dari guru di UPTD-PK Dewantara dapat lebih ditingkatkan lagi dimasa-masa yang akan datang. 
Dapat dijelaskan bahwa nilai rata-rata (mean) jawaban responden tentang variabel kinerja sebesar 3,837. Apabila dihubungkan dengan skala yang ditentukan dalam penelitian ini yaitu: (1) sangat tidak setuju, (2) tidak setuju, (3) netral, (4) setuju, (5) sangat setuju, maka kategori jawaban responden secara rata-rata berada pada skala (4) atau pada kondisi setuju, dengan nilai standar deviasi sebesar 0,746 menunjukkan bahwa sebaran data sudah baik, karena nilai tersebut tidak melebihi tiga kali nilai mean.

Hal ini berarti secara umum guru di UPTD-PK Dewantara telah memiliki kinerja yang tinggi yang didukung kompetensi, pemberdayaan dan pelatihan yang baik dari guru di UPTD-PK Dewantara. Kinerja guru di UPTD-PK Dewantara yang tinggi tersebut dapat terlihat dari: guru dapat mengerjakan banyak tugas, guru dapat mengajar siswa dengan baik sesuai tujuan pendidikan, guru dapat menyelesaikan pekerjaan sesuai waktu yang ditentukan, guru selalu hadir tepat waktu pada setiap hari jam kerja dan para guru dapat bekerjasama dengan guru lain.

\section{TAHAPAN ANALISIS SEM}

\section{UJI VALIDITAS}

Uji validitas sebagai mana telah dilakukan dengan tujuan untuk mengetahui tingkat kemampuan suatu instrumen atau alat pengumpul data dalam mengungkap sesuatu yang menjadi sasaran pokok pengukuran yang dilakukan. Suatu instrumen dikatakan valid apabila instrumen tersebut mampu mengukur apa yang ingin diungkapkan (Sutrisno, 1993). Dalam SEM pengujian validitas dilakukan dengan Confirmatory Factor Analysis (CFA) masing-masing konstruk yaitu dengan melihat nilai Loading Factor masing-masing indikator. Suatu indikator dikatakan valid apabila nilai loading factornya > 0,60 (Ghozali, 2013). Uji validitas dalam penelitian ini dilakukan terhadap konstruk eksogen (pelatihan dan pemberdayaan) dan konstruk endogen (kompetensi dan kinerja).

\section{UJI CFA VARIABEL EKSOGEN}

Dalam penelitian ini terdapat dua konstruk eksogen yaitu variabel pelatihan dan pemberdayaan. Variabel pelatihan dibentuk oleh 5 (lima) indikator dan variabel pemberdayaan dibentuk oleh 4 (empat) indikator. Berikut akan diuraikan mengenai uji CFA konstruk eksogen seperti pada Gambar 2 berikut ini:

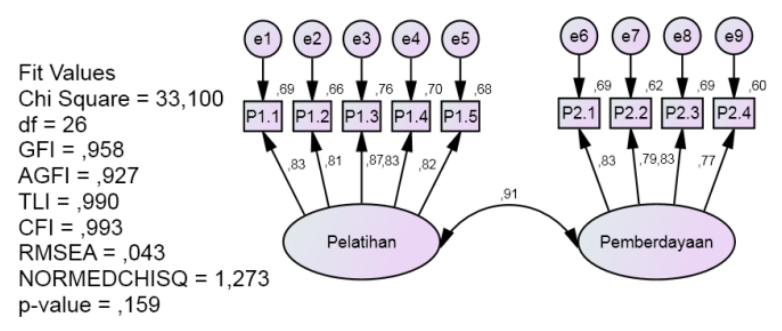

Gambar 2. CFA Variabel Konstruk Eksogen 
Berdasarkan Gambar 2 dapat kita ketahui bahwa seluruh indikator dari variabel eksogen datanya sudah valid. Hal ini diketahui dari nilai loading factor seluruh indikator dari variabel pelatihan dan pemberdayaan tidak ada yang di bawah 0,60 (Ghozali, 2013).

\section{UJI CFA SELURUH VARIABEL EKSOGEN}

Dalam penelitian ini terdapat dua konstruk endogen yaitu variabel kompetensi dan kinerja. Variabel kompetensi dibentuk oleh 5 (lima) indikator dan variabel kinerja dibentuk oleh 5 (lima) indikator. Untuk melihat apakah konstruk variabel endogen seluruh indikatornya valid maka dilakukan uji validitas seperti pada Gambar 3 berikut ini:

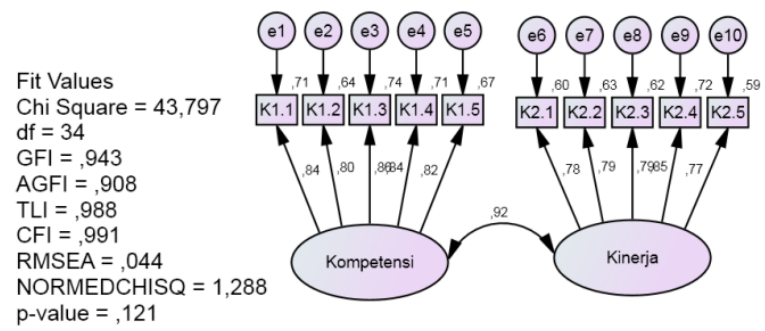

Gambar 3. CFA Variabel Endogen

Berdasarkan Gambar 3 di atas dapat kita ketahui bahwa seluruh indikator dari variabel endogen datanya sudah valid. Hal ini diketahui dari nilai loading factor seluruh indikator dari variabel endogen tidak ada yang di bawah 0,60 (Ghozali, 2013).

\section{UJI RELIABILITAS}

Reliabilitas konstruk adalah ukuran mengenai konsistensi internal dari indikator-indikator sebuah konstruk yang menunjukkan derajat sampai dimana masing-masing indikator itu mengindikasikan sebuah konstruk/faktor laten yang umum. Dengan kata lain bagaimana hal-hal yang spesifik saling membantu dalam menjelaskan fenomena yang umum. Pada dasarnya uji reliabilitas menunjukan sejauh mana suatu alat ukur dapat memberikan hasil yang relatif sama bila dilakukan pengukuran kembali pada subyek yang sama. Uji reliabilitas dilakukan dengan tiga cara yaitu Construct Reliability (CR), Variance Extracted (VE) dan Dicriminant Validity (DV). Hasil uji reliabilitas dapat dilihat dalam Tabel 1 berikut ini:

Tabel 1

Uji Reliabilitas

\begin{tabular}{|c|c|c|c|c|c|c|c|c|}
\hline & & Indikator & SL & $\mathrm{SL}^{2}$ & 1-SL ${ }^{2}$ & $\mathrm{CR}$ & $\mathrm{VE}$ & $\mathrm{DV}$ \\
\hline $\mathrm{P} 1.1$ & $<<--$ & Pelatihan & 0,831 & 0,691 & 0,309 & & & \\
\hline $\mathrm{P} 1.2$ & $<---$ & Pelatihan & 0,811 & 0,658 & 0,342 & & & \\
\hline $\mathrm{P} 1.3$ & $<--$ & Pelatihan & 0,871 & 0,759 & 0,241 & & & \\
\hline $\mathrm{P} 1.4$ & $<--$ & Pelatihan & 0,835 & 0,697 & 0,303 & & & \\
\hline \multirow[t]{2}{*}{$\mathrm{P} 1.5$} & $<--$ & Pelatihan & 0,823 & 0,677 & 0,323 & & & \\
\hline & & $\Sigma$ & 4,171 & 3,481 & 1,519 & 0,920 & 0,696 & 0,834 \\
\hline \multicolumn{3}{|c|}{$\mathrm{CR}=\sum(\mathrm{SL})^{2} / \Sigma(\mathrm{SL})^{2}+\sum\left(1-\mathrm{SL}^{2}\right)$} & & & & 0,920 & & \\
\hline \multicolumn{3}{|c|}{$\mathrm{VE}=\sum\left(\mathrm{SL}^{2}\right) / \Sigma\left(\mathrm{SL}^{2}\right)+\sum\left(1-\mathrm{SL}^{2}\right)$} & & & & & 0,696 & \\
\hline
\end{tabular}




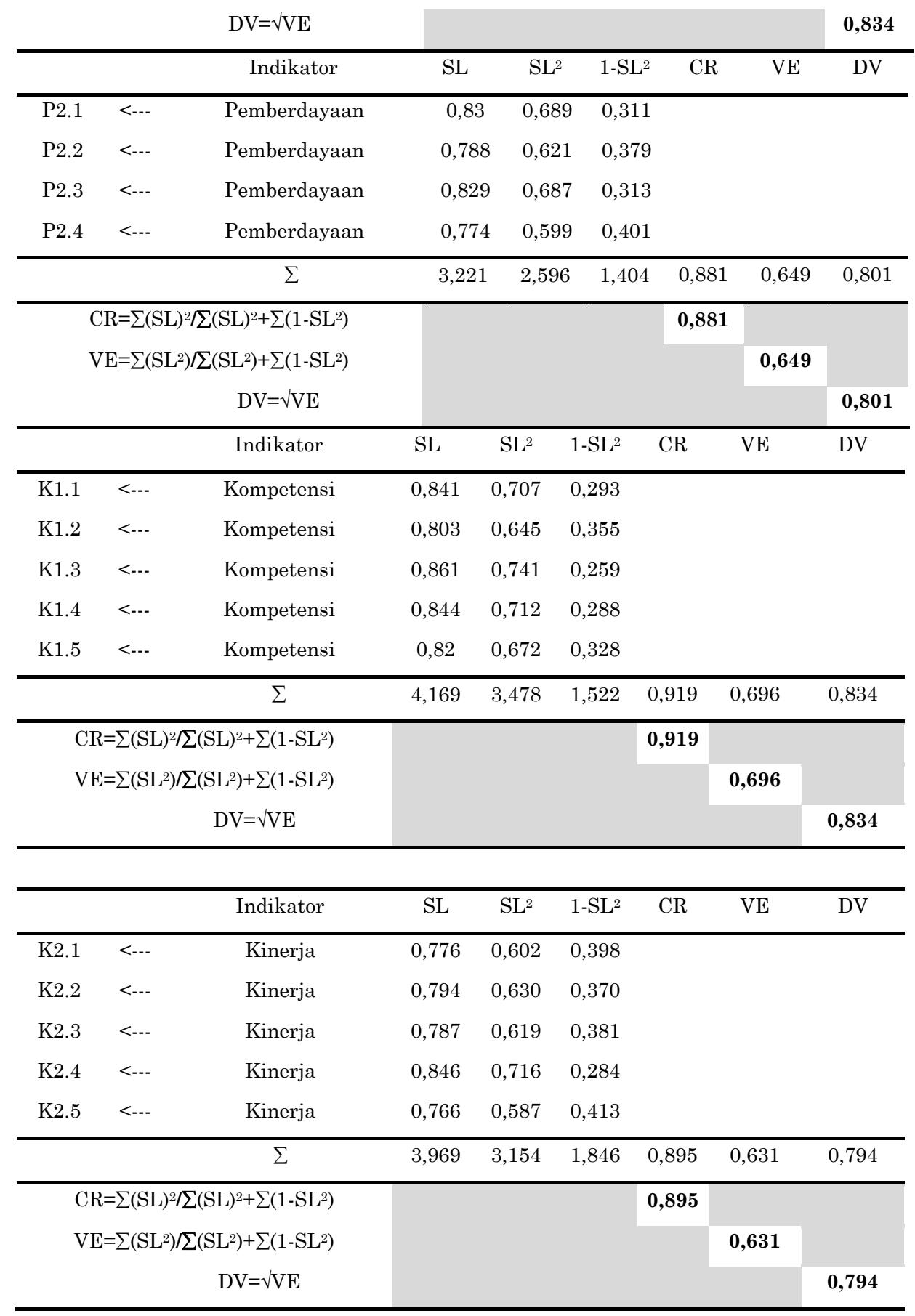

Berdasarkan data seperti yang ditunjukkan dalam Tabel 1 dapat dijelaskan bahwa keseluruhan nilai CR berada di atas atau lebih besar dari 0,70 dan nilai VE berada di atas 0,50. Dengan demikian keseluruhan konstruk dalam penelitian ini adalah reliabel sehingga model yang dibentuk adalah layak untuk diuji dalam tahap selanjutnya.

Sebelum mengukur Discriminant Validity terlebih dahulu harus diketahui nilai korelasi antar konstruk dalam model penelitian sebagai pembanding terhadap nilai akar kuadrat. Tabel 2 menunjukkan nilai korelasi antar konstruk laten. 
Tabel 2 Kesimpulan Hasil Pengujian

Discriminant Validity

\begin{tabular}{ccccc}
\hline & Pelatihan & Pemberdayaan & Kompetensi & Kinerja \\
\hline Pelatihan & $\mathbf{0 , 8 3 4}$ & & & \\
Pemberdayaan & 0,357 & $\mathbf{0 , 8 0 1}$ & & \\
Kompetensi & 0,365 & 0,404 & $\mathbf{0 , 8 3 4}$ & \\
Kinerja & 0,349 & 0,364 & 0,349 & $\mathbf{0 , 7 9 4}$ \\
\hline
\end{tabular}

Berdasarkan Tabel 2 jelas terlihat bahwa masing-masing konstruk laten memiliki DV yang baik, hal ini dapat dilihat dari nilai akar kuadrat dari $\mathrm{VE}(\sqrt{ } \mathrm{VE})$ masing-masing konstruk laten yang lebih tinggi nilainya dibandingkan dengan nilai korelasi antara konstruk. Sehingga dapat dikatakan bahwa setiap variabel yang ada dalam penelitian ini sudah reliabel.

Dapat dijelaskan nilai DV untuk konstruk pelatihan sebesar 0,834 lebih besar nilainya dari korelasi terhadap pemberdayaan 0,357, kompetensi 0,365, dan kinerja 0,349. Nilai DV untuk konstruk pemberdayaan sebesar 0,801 lebih besar nilainya dari korelasi terhadap kompetensi 0,404 dan kinerja 0,363. Begitu juga dengan nilai DV untuk konstruk kompetensi sebesar 0,834 lebih besar nilainya dari korelasi terhadap kinerja 0,349.

\section{PENGUJIAN ASUMSI SEM}

\section{UKURAN SAMPEL}

Pada analisis SEM, ukuran sampel yang sesuai adalah antara 100-200 (Hair et al. 1999). Dalam penelitian ini terdapat 19 indikator sehingga jumlah sampel bisa berkisar antara 95-190 responden. Jumlah sampel ditentukan dengan mengalikan jumlah indikator dengan 8, sehingga total sampel sebanyak 19 × $8=152$ responden. Seluruh kuesioner yang disebarkan yaitu sebanyak 152 kuesioner yang telah dikembalikan oleh responden dan keseluruhannya berada dalam keadaan baik dan dapat diolah. Setelah proses analisis data dengan menggunakan perangkat AMOS- 20 dengan model SEM tidak terdapat data yang outlier (data yang ekstrem atau sangat berbeda dengan data lainnya), sehingga tidak ada data yang harus dibuang. Jadi jumlah sampel tetap sebanyak 152 responden.

\section{UJI NORMALITAS DATA}

Berdasarkan data seperti yang diperlihatkan Output AMOS-20 bahwa nilai critical ratio skewness tidak ada satupun nilai univariate yang berada di luar rentang nilai $\pm 2,58$. Dengan demikian dapat disimpulkan keseluruhan data secara univariate adalah berdistribusi normal, demikian pula secara multivariate nilai critical ratio kurtosis juga berada dalam rentang $\pm 2,58$ yaitu sebesar 0,519 maka dengan demikian dapat disimpulkan baik secara univariate dan multivariate data dalam penelitian ini berdistribusi normal. 
Tabel 3 Assessment of Normality

\begin{tabular}{lllllcc}
\hline Variable & min & max & skew & c.r. & kurtosis & c.r. \\
\hline K2.5 & 2,000 & 5,000 &,- 215 & $-1,084$ &,- 574 & $-1,444$ \\
K2.4 & 2,000 & 5,000 &,- 269 & $-1,355$ &,- 625 & $-1,574$ \\
K2.3 & 2,000 & 5,000 &,- 402 & $-2,022$ &, 180 &, 452 \\
K2.2 & 2,000 & 5,000 &,- 215 & $-1,083$ &,- 200 &,- 503 \\
K2.1 & 2,000 & 5,000 &,- 182 &,- 914 &,- 226 &,- 570 \\
K1.5 & 2,000 & 5,000 &,- 094 &,- 475 &,- 491 & $-1,234$ \\
K1.4 & 2,000 & 5,000 &,- 309 & $-1,556$ &,- 588 & $-1,481$ \\
K1.3 & 2,000 & 5,000 &,- 213 & $-1,070$ &,- 290 &,- 730 \\
K1.2 & 2,000 & 5,000 &,- 106 &,- 531 &,- 178 &,- 448 \\
K1.1 & 2,000 & 5,000 &,- 120 &,- 605 &,- 491 & $-1,236$ \\
P2.4 & 2,000 & 5,000 &,- 267 & $-1,345$ &,- 690 & $-1,737$ \\
P2.3 & 2,000 & 5,000 &,- 311 & $-1,567$ &,- 154 &,- 387 \\
P2.2 & 2,000 & 5,000 &,- 401 & $-2,021$ &,- 035 &,- 089 \\
P2.1 & 2,000 & 5,000 &,- 382 & $-1,923$ &,- 165 &,- 416 \\
P1.5 & 2,000 & 5,000 &,- 235 & $-1,183$ &,- 467 & $-1,175$ \\
P1.4 & 2,000 & 5,000 &,- 047 &,- 235 &,- 330 &,- 831 \\
P1.3 & 2,000 & 5,000 &,- 157 &,- 791 &,- 224 &,- 563 \\
P1.2 & 2,000 & 5,000 &,- 210 & $-1,057$ &,- 337 &,- 849 \\
P1.1 & 2,000 & 5,000 &,- 187 &,- 941 &,- 685 & $-1,724$ \\
K2.5 & 2,000 & 5,000 &,- 215 & $-1,084$ &,- 574 & $-1,444$ \\
\hline Multivariate & & & & & 2,381 &, 519 \\
\hline & & & & & &
\end{tabular}

\section{UJI OUTLIER DATA}

Angka ekstrim (outliers) adalah observasi yang muncul dengan nilai-nilai ekstrim baik secara univariate maupun multivariate, muncul karena kombinasi karakteristik yang unik yang dimilikinya dan terlihat sangat jauh berbeda dengan observasi-observasi lainnya (Ferdinand, 2014). Dalam penelitian ini pengujian data outlier menggunakan uji Mahalanobis Distance, dengan membandingkan nilai $\mathrm{p} 1$ dan p2. Nilai $\mathrm{p} 1$ dan $\mathrm{p} 2$ di atas 0,05 menunjukkan tidak ada data outliers lagi. Berdasarkan hasil analisis data outlier terlihat bahwa keseluruhan data memiliki nilai p1 atau p2 di atas 0,05 dengan demikian keselurahan data dalam penelitian tidak terdapat data yang outlier.

\section{MULTIKOLINIERITAS DAN SINGULIRITAS DATA}

Berdasarkan hasil uji multikolinieritas memperlihatkan nilai Determinant of sample covariance matrix sebesar 0,300 sangat jauh dari 0 maka dapat dikatakan bahwa tidak terdapat multikolinieritas antar variabel endogen dalam penelitian ini. 


\section{HASIL DAN PEMBAHASAN}

\section{FULL MODEL SEBELUM DIMODIFIKASI}

Uji full model SEM sebelum modifikasi bertujuan untuk melihat sejauh mana model dasar yang dibentuk dalam penelitian ini memenuhi kriteria goodness of fit sehingga model dapat menggambarkan fenomena penelitian tanpa adanya modifikasi. Model full SEM sebelum modifikasi ditampilkan dalam Gambar 4 berikut ini:

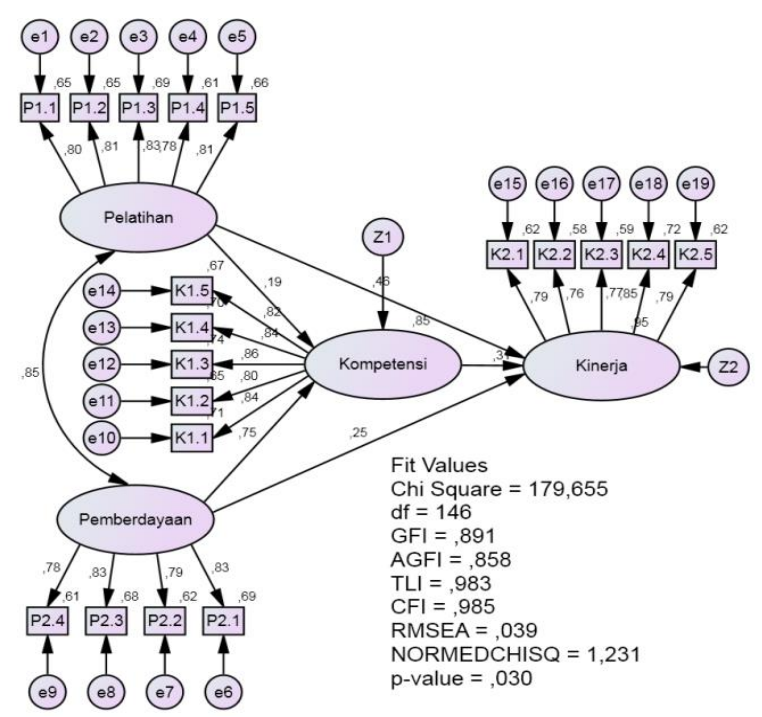

\section{Gambar 4. Full Model Sebelum Dimodifikasi}

Berdasarkan data dalam Gambar 4 terlihat bahwa belum seluruh nilai Goodness Of Fit (GOF) memenuhi kriteria yang dipersyaratkan, misalnya nilai GFI yang masih marginal $(0,891 \leq 0,90)$, nilai AGFI yang masih marginal $(0,858 \leq 0,90)$ dan nilai $p$-value yang masih marginal. Dengan demikian model penelitian belum sesuai dan belum mampu menjelaskan model penelitian dengan tepat dan baik, sehingga dengan demikian model perlu dilakukan modifikasi.

\section{FULL MODEL SETELAH DIMODIFIKASI}

Uji kesesuaian model setelah modifikasi dilakukan dengan cara menghubungkan (korelasi) antar error pada setiap indikator yang disarankan oleh sistem. Tujuannya adalah untuk menaikkan nilai GOF agar model benar layak dan tepat menjelaskan model penelitian. 


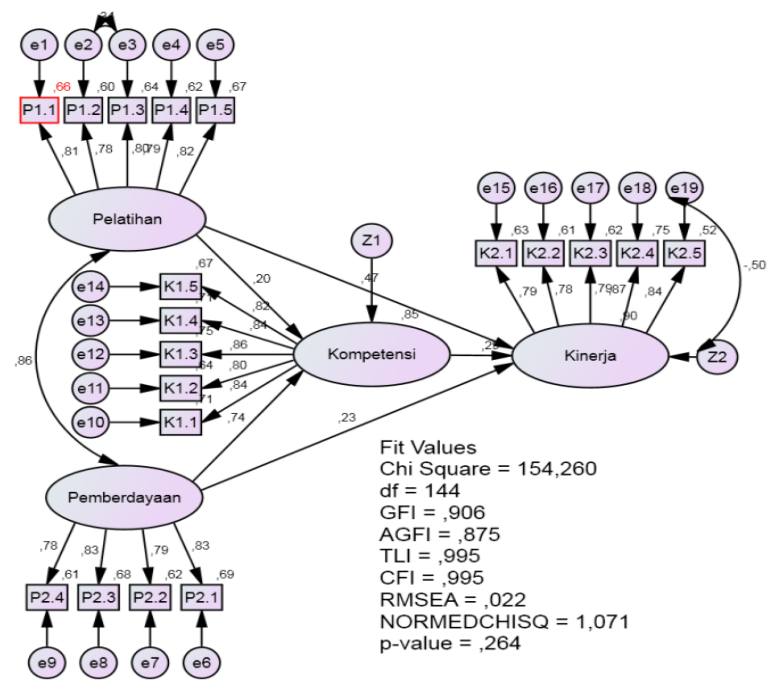

Gambar 5. Full Model Setelah Dimodifikasi

Berdasarkan Gambar 5 dapat dijelaskan menunjukkan bahwa secara umum semua konstruk yang digunakan untuk membentuk model penelitian ini, telah memenuhi kriteria goodness of fit indeks yang telah ditetapkan seperti nilai chi-square, nilai GFI, nilai TLI, nilai CFI, RMSEA, CMIN/DF dan nilai pvalue. Kecuali nilai AGFI yang masih marginal namun sudah mendekati baik.

Selanjutnya akan disajikan nilai korelasi antar konstruk setelah dimodifikasi yang akan menjadi pedoman peneliti dalam menjawab hipotesis yang ada dalam penelitian ini. Nilai regresi setelah dimodifikasi akan diuraikan dalam Tabel 4 berikut ini:

Tabel 4 Pengaruh Variabel Dependen terhadap Variabel Independen

\begin{tabular}{cccccccc}
\hline \multicolumn{2}{c}{ Variabel Laten } & Estimate & $\begin{array}{c}\text { Std. } \\
\text { Estimate }\end{array}$ & S.E. & C.R. & P \\
\hline Kompetensi & $<---$ & Pelatihan &, 203 &, 212 &, 131 & 2,615 &, 006 \\
Kompetensi & $<---$ & Pemberdayaan &, 740 &, 773 &, 143 & 5,406 & $* * *$ \\
Kinerja & $<---$ & Pelatihan &, 474 &, 424 &, 092 & 4,594 & $* * * *$ \\
Kinerja & $<---$ & Kompetensi &, 290 &, 249 &, 113 & 3,196 &, 028 \\
Kinerja & $<---$ & Pemberdayaan &, 229 &, 206 &, 133 & 3,546 &, 022 \\
\hline
\end{tabular}

Berdasarkan hasil analisis data seperti yang ditampilkan dalam Tabel 4, maka persamaan struktural sebagai berikut :

Persamaan Struktural I :

$$
\begin{array}{ll}
\mathrm{K} 1= & b_{1} \mathrm{P} 1+b_{2} \mathrm{P} 2+\mathrm{Z}_{1} \\
\mathrm{~K} 1= & 0,203 \mathrm{P} 1+0,740 \mathrm{P} 2+\mathrm{Z}_{1}
\end{array}
$$

Persamaan Struktural II :

$$
\begin{array}{ll}
\mathrm{K} 2= & b_{1} \mathrm{P} 1+b_{2} \mathrm{P} 2+b_{3} \mathrm{~K} 1+\mathrm{Z}_{2} \\
\mathrm{~K} 2= & 0,474 \mathrm{P} 1+0,229 \mathrm{P} 2+0,290 \mathrm{~K} 1+\mathrm{Z}_{2}
\end{array}
$$




\section{PEMBAHASAN}

\section{PENGARUH PELATIHAN TERHADAP KOMPETENSI GURU}

Pengaruh pelatihan terhadap kompetensi adalah signifikan dengan nilai koefesien estimate standardized regression weight sebesar 0,203 (20,3\%), nilai probabilitas atau signifikansi sebesar 0,006 (signifikan) dan nilai C.R sebesar 2,615 (terima H1). Dengan kata lain bahwa pelatihan berpengaruh signifikan terhadap kompetensi guru di UPTD-PK Dewantara.

Pelatihan adalah suatau kegiatan untuk memperbaiki kemampuan kerja seseorang dalam kaitannya dengan aktivitas tertentu (Ranupanjoyo \& Husnan, 1995). Selanjutnya Saydam (1996) menjelaskan bahwa pengembangan sumber daya manusia melalui pendidikan dan pelatihan merupakan kegiatan yang harus dilakukan organisasi baik instansi pemerintah maupun perusahaan agar pengetahuan, kemampuan dan keterampilan pegawai/karyawan sesuai dengan tuntutan pekerjaan yang mereka lakukan.

UPTD-PK Dewantara menyadari betul akan pentingnya pelatihan untuk meningkatkan kompetensi para guru di SMA Negeri 1 Dewantara, SMA Negeri 2 Dewantara dan guru SMK Negeri 1 Dewantara. Pelatihan yang diberikan di UPTD-PK Dewantara bertujuan untuk memperbaiki performansi guru dalam mencerdaskan para peserta didiknya. Pelatihan yang diberikan diantaranya mencakup tentang penyusunan silabus dan RPP, metode dan teknik mengajar yang efektif, penggunaan media belajar yang tepat dan pelatihan-pelatihan lain yang berfungsi untuk menunjang tugas guru dalam melaksanakan tugas pembelajaran. Pelatihan yang diberikan kepada para guru di UPTD-PK Dewantara khususnya para guru di SMA Negeri 1 Dewantara, SMA Negeri 2 Dewantara dan guru SMK Negeri 1 Dewantara bertujuan untuk menambah penguasaan guru dalam berbagai ketrampilan dan teknik mengajar yang pelaksanaannya dilakukan secara terperinci dan rutin. Hal ini dilakukan dalam upaya meningkatkan kompetensi guru di UPTD-PK Dewantara.

\section{PENGARUH PEMBERDAYAAN TERHADA KOMPETENSI GURU}

Pengaruh pemberdayaan adalah signifikan terhadap kompetensi. Hal ini dapat dilihat dari nilai koefesien estimate standardized regression weight sebesar 0,740 (74\%), nilai probabilitas atau signifikansi sebesar 0,0001 (signifikan) dan nilai C.R sebesar 5,406 (terima H2). Dengan demikian dapat disimpulkan bahwa pemberdayaan berpengaruh signifikan terhadap kompetensi guru di UPTD-PK Dewantara.

Program pelatihan dan pemberdayaan guru pada dasarnya dapat meningkatkan ketrampilan, pengetahuan dan pengalaman guru terhadap pekerjaannya. Hal ini sejalan dengan pendapat dari Pradiansyah (2002) yang menyatakan bahwa pemberdayaan dapat membuat karyawan lebih leluasa dalam mengeluarkan segala kemampuan yang ada pada dirinya.

Dengan adanya pemberdayaan, guru di UPTD-PK Dewantara memiliki kebebasan untuk mengeksplor semua potensi dan kompetensi yang mereka miliki. Sejauh hal tersebut tidak melanggar peraturan yang ada di UPTD-PK Dewantara khususnya peraturan yang ada di SMA Negeri 1 Dewantara, SMA Negeri 2 Dewantara dan SMK Negeri 1 Dewantara. Pemberdayaan guru yang ada di UPTD-PK Dewantara berupa pemberian wewenang kepada para guru untuk merencanakan, mengendalikan dan membuat keputusan tentang kegiatan pembelajaran peserta didik yang menjadi 
tanggung jawabnya, tanpa harus mendapat otoritas secara eksplisit dari Kepala Sekolah. Melalui hal tersebut diharapkan agar pemberdayaan guru di UPTD-PK Dewantara dapat berjalan dengan efektif.

\section{PENGARUH PELATIHAN TERHADAP KINERJA GURU}

Pengaruh pelatihan adalah signifikan terhadap kinerja. Hal ini dapat dilihat dari nilai koefesien estimate standardized regression weight sebesar $0,474(47,4 \%)$, nilai probabilitas atau signifikansi sebesar 0,0001 (signifikan) dan nilai C.R sebesar 4,594 (terima H3). Dengan demikian dapat disimpulkan bahwa pelatihan berpengaruh signifikan terhadap kinerja guru di UPTD-PK Dewantara.

Menurut Rivai (2005), pendidikan dan pelatihan berfungsi untuk memperbaiki perilaku (performance) kerja, yang meliputi aspek-aspek: pengetahuan, keterampilan, dan sikap keperibadian yang dituntut oleh tugas pekerjaannya. Perbaikan dan peningkatan perilaku kerja diperlukan agar pegawai lebih mampu melaksanakan tugas-tugas dan diharapkan lebih berhasil dalam upaya pelaksanaan program kerja instansi. Selanjutnya menurut Raymond (2010), untuk memecahkan masalah terkait dengan peningkatan kinerja karyawan ada beberapa kemungkinan yang dapat dilakukan oleh perusahaan antara lain melalui pemberian motivasi dan pelatihan kerja.

Pemberian pelatihan kepada para guru di UPTD-PK Dewantara harus dilakukan secara kontinyu dan berkelanjutan guna meningkatkan kinerja guru dalam kegiatan proses belajar mengajar. Guru merupakan jabatan profesional yang secara intensif harus dibekali pengalaman melalui pelatihan, karena dengan pelatihan dapat meningkatkan pengetahuan dan keterampilan guru dalam melaksanakan tugas-tugas. Dengan adanya pelatihan yang dilakukan maka keahlian, pengetahuan dan pengalaman akan meningkat sehingga akan memberikan dampak yang positif terhadap peningkatan guru di UPTD-PK itu sendiri.

\section{PENGARUH PEMBERDAYAAN TERHADAP KINERJA GURU}

Pemberdayaan berpengaruh signifikan terhadap kinerja. Hal ini dapat dilihat dari nilai koefesien estimate standardized regression weight sebesar 0,229 (22,9\%), nilai probabilitas atau signifikansi sebesar 0,022 (signifikan) dan nilai C.R sebesar 3,546 (terima H4). Dengan demikian dapat disimpulkan bahwa pemberdayaan berpengaruh signifikan terhadap kinerja guru di UPTD-PK Dewantara.

Menurut Judge dalam Pujisari (2001) mengatakan bahwa pemberdayaan berpengaruh terhadap peningkatan kinerja. Sejalan dengan pendapat Judge dalam Pujisari (2001) tersebut, Duvall (1999) juga mengungkapkan bahwa pencapaian prestasi juga berupa keberhasilan pemberdayaan melalui jaringan keberhasilan dalam bentuk kinerja peran karyawan.

Demikian halnya dengan UPTD-PK Dewantara, pemberdayaan guru juga menjadi faktor penting suatu faktor penting yang berkontribusi dalam peningkatan kinerja di SMA Negeri 1 Dewantara, SMA Negeri 2 Dewantara dan SMK Negeri 1 Dewantara. Bentuk pemberdayaan yang diterapkan kepada para guru di UPTD-PK Dewantara berupa pemberian tanggung jawab dan wewenang dari Kepala Sekolah kepada para guru, yang melibatkan adanya sharing informasi dan pengetahuan untuk memandu dan mengembangkan para guru dalam bertindak sesuai dengan tujuan organisasi. Dengan adanya pemberian tanggung jawab dan wewenang tersebut diharapkan para guru dapat lebih leluasa mengembangkan kreativitas mereka dalam mengajar para peserta didiknya. Sehingga kegiatan belajar 
mengajar di kelas dapat berjalan lebih efisien dan efektif.

\section{PENGARUH KOMPETENSI TERHADAP KINERJA GURU}

Kompetensi berpengaruh signifikan terhadap kinerja guru. Hal ini dapat dilihat dari nilai koefesien estimate standardized regression weight sebesar 0,290 (29\%), nilai probabilitas atau signifikansi sebesar 0,028 (signifikan) dan nilai C.R sebesar 3,196 (terima H6). Dengan demikian dapat disimpulkan bahwa kompetensi berpengaruh signifikan terhadap kinerja guru di UPTD-PK Dewantara.

Menurut organisasi industri psikolog di Amerika Serikat (dalam Moeheriono, 2009) perusahaan di era modern ini, membutuhkan sumber daya yang handal dan memiliki kompetensi untuk memberikan kinerja terbaik bagi perusahaan. Selain itu, Wibowo (2005) mengemukakan ada beberapa faktor-faktor yang dapat mempengaruhi sumber daya manusia dalam menjalankan kinerjanya, diantaranya adalah kemampuan berdasar pada pengetahuan dan keterampilan serta kompetensi yang sesuai dengan pekerjaannya.

Kompetensi guru di UPTD-PK Dewantara merupakan kemampuan dan kewenangan guru dalam melaksanakan profesi keguruannya. Guru yang memiliki kompetensi akan memiliki kemampuan mengajar di atas rata-rata kemampuan mengajar guru yang lain. Peserta didik akan lebih mudah menerima materi pelajaran yang disampaikan oleh guru dikarenakan guru tersebut menguasai materi, metode dan teknik mengajar yang baik serta dapat memanfaat media (teknologi) yang ada guna memaksimalkan penyerapan materi pelajaran di kelas. Guru yang berkompetensi akan dapat menggunakan semua fasilitas dan mengerahkan segala kemampuan yang dia miliki untuk mencerdaskan peserta didiknya. Jadi sangatlah jelas bahwa kompetensi guru di UPTD-PK Dewantara dapat memberikan efek yang signifikan terhadap peningkatan kinerja guru dalam melaksanakan tugastugas yang diembankan kepadanya.

\section{KOMPETENSI MEMEDIASI PENGARUH PELATIHAN TERHADAP KINERJA GURU}

Berdasarkan hasil analisis dengan menggunakan sobel test dapat diketahui bahwa kompetensi memediasi pengaruh antara pelatihan terhadap kinerja. Dengan nilai koefesien estimate standardized regression weight sebesar 0,059 (5,9\%), nilai probabilitas atau signifikansi sebesar 0,185 dan nilai C.R sebesar 1,327 (terima H7). Dengan demikian dapat disimpulkan bahwa kompetensi memediasi secara full mediation pengaruh pelatihan terhadap kinerja guru di UPTD-PK Dewantara.

Pemberdayaan akan sangat menentukan semangat atau dorongan untuk mengaktualisasi diri, berprestasi, dan menggunakan wewenang secara efektif untuk memanfaatkan kemampuan sumber daya manusia yang seoptimal mungkin yang pada akhirnya akan sangat mempengaruhi kinerja dalam mencapai tujuan organisasi (Riniwati, 2011).

Pengaruh kompetensi sebagai variabel intervening antara pelatihan terhadap kinerja guru di UPTD-PK Dewantara dalam penelitian ini lebih kecil dari pengaruh langsung antara pelatihan terhadap kinerja guru di UPTD-PK Dewantara, artinya peran kompetensi dalam memediasi pelatihan terhadap kinerja guru di UPTD-PK Dewantara memiliki peran yang lebih kecil dibandingkan dengan pengaruh secara langsung. 


\section{KOMPETENSI MEMEDIASI PENGARUH PEMBERDAYAAN TERHADAP KINERJA GURU}

Berdasarkan hasil analisis dengan menggunakan sobel test dapat diketahui bahwa kompetensi memediasi pengaruh antara pemberdayaan terhadap kinerja. Dengan nilai koefesien estimate standardized regression weight sebesar 0,214 (21,4\%), nilai probabilitas atau signifikansi sebesar 0,021 dan nilai C.R sebesar 2,299 (terima H7). Dengan demikian dapat disimpulkan bahwa kompetensi memediasi secara partial mediation pengaruh pemberdayaan terhadap kinerja guru di UPTD-PK Dewantara.

Pelatihan bagi organisasi dilakukan untuk meningkatkan produktivitas, sedangkan pelatihan bagi karyawan dilakukan untuk meningkatkan kinerja karena setiap manusia perlu belajar dan berlatih agar memiliki kompetensi dan kemampuan yang memadai dalam mengerjakan suatu pekerjaan (Mukzam et al., 2013).

Pengaruh kompetensi sebagai variabel intervening antara pemberdayaan terhadap kinerja guru di UPTD-PK Dewantara dalam penelitian ini lebih kecil dari pengaruh langsung antara pemberdayaan terhadap kinerja guru di UPTD-PK Dewantara, artinya peran kompetensi dalam memediasi pemberdayaan terhadap kinerja guru di UPTD-PK Dewantara memiliki peran yang lebih kecil dibandingkan dengan pengaruh secara langsung.

Penelitian ini sejalan dengan hasil penelitian dari Kambey dan Suharnomo (2013), Riniwati (2011) dan penelitian dari Fadzilah (2006) yang menemukan bahwa kompetensi memediasi pengaruh antara pemberdayaan terhadap kinerja.

\section{KESIMPULAN}

Pelatihan memiliki pengaruh yang signifikan terhadap kompetensi guru di UPTD-PK Dewantara. Antara pelatihan dengan kompetensi mempunyai hubungan yang positif. Jika pelatihan yang diberikan cukup maka akan menciptakan kompetensi guru yang tinggi pula.

Pemberdayaan memiliki pengaruh yang signifikan terhadap kompetensi guru di UPTD-PK Dewantara. Semakin baik pemberdayaan yang diberikan kepada guru maka kompetensi guru akan dapat meningkat.

Pelatihan memiliki pengaruh yang signifikan terhadap kinerja guru di UPTD-PK Dewantara. Semakin baik pelatihan yang diterima guru maka kinerja guru akan meningkat sejalan dengan keefektifan dan ketepatan pelatihan yang diterimanya.

Pemberdayaan memiliki pengaruh yang signifikan terhadap kinerja guru di UPTD-PK Dewantara. Ini mengandung makna bahwa jika guru diberikan wewenang dan tanggungjawab dalam proses belajar mengajar di kelas maka guru akan lebih efektif dalam kegiatan pembelajaran di kelas, sehingga kinerja guru juga akan meningkat.

Kompetensi memiliki pengaruh yang signifikan terhadap kinerja guru di UPTD-PK Dewantara. Hasil ini menegaskan bahwa antara kompetensi dengan kinerja mempunyai arah hubungan yang positif. Dengan kata lain jika kompetensi meningkat maka kinerja guru juga akan meningkat.

Kompetensi memediasi secara full mediation pengaruh pelatihan terhadap kinerja guru di UPTDPK Dewantara. Hal ini menunjukkan bahwa kompetensi dapat menjadi perantara antara pelatihan 
terhadap kinerja guru. Meskipun pengaruh kompetensi ini dinilai masih terlalu kecil bila dibandingkan dengan pengaruh langsung antara pelatihan terhadap kinerja guru.

Kompetensi memediasi secara partial mediation pengaruh pemberdayaan terhadap kinerja guru di UPTD-PK Dewantara. Ini menunjukkan bahwa kompetensi dapat menjadi pendahulu terciptanya kinerja guru yang optimal, dimana pemberdayaan juga harus diperhatikan.

\section{SARAN}

Untuk meningkatkan pelatihan guru di UPTD-PK Dewantara diharapkan kepada Kepala Dinas Pendidikan dan Kebudayaan Kabupaten Aceh Utara untuk berperan aktif dalam memberikan pelatihan kepada para guru di UPTD-PK Dewantara, dengan cara: selalu melakukan kegiatan pelatihan terutama untuk penerapan kebijakan-kebijakan dan kurikulum baru khususnya di lingkungan UPTD-PK Dewantara, membuat seminar-seminar dan training terkait dengan pengembangan soft skill guru, sering mengadakan workshop untuk meningkatkan kompetensi guru dalam mengajar.

Untuk meningkatkan pemberdayaan guru di UPTD-PK Dewantara diharapkan kepada para guru untuk dapat mengeluarkan semua potensi mengajar yang mereka miliki dengan baik, misalnya dengan cara: menguasai materi pelajaran dengan baik, menyusun silabus dan RPP sesuai dengan kurikulum 2013, menggunakan teknik mengajar yang efektif, menggunakan media pembelajaran dengan tepat dan lain sebagainya.

Untuk meningkatkan kompetensi guru di UPTD-PK Dewantara, peneliti menyarankan kepada Kepala Sekolah yang di SMA Negeri 1 Dewantara, SMA Negeri 2 Dewantara dan SMK Negeri 1 Dewantara untuk mengawasi dan memeriksa apakah setiap guru telah menerapkan metode mengajar yang sesuai dengan kurikulum 2013, baik dari segi penyusunan silabus dan RPP serta pengimplementasiannya di dalam kelas.

Untuk dapat meningkatkan kinerja guru di UPTD-PK Dewantara, peneliti menyarankan agar tiap guru khususnya guru di SMA Negeri 1 Dewantara, guru SMA Negeri 2 Dewantara dan guru SMK Negeri 1 Dewantara harus dapat mengajar siswa dengan baik sesuai tujuan pendidikan. Jika para guru telah dapat mengajar para peserta didiknya dengan baik maka diharapkan kinerja guru di UPTD-PK Dewantara akan meningkat yang ditandai dengan pencapaian nilai rata-rata Ujian Nasional siswa, tingkat kelulusan siswa dalam melanjutkan pendidikan di perguruan tinggi negeri, keikutsertaan siswa dalam berbagai perlombaan di tingkat provinsi dan nasional, serta indikator-indikator yang lain yang menunjukkan bahwa kinerja guru di di UPTD-PK Dewantara telah tercapai dengan optimal.

\section{KETERBATASAN PENELITIAN}

Pada waktu menyebar kuesioner ada beberapa responden yang tidak dapat mengisi kuisioner dengan baik karena responden dalam keadaan sibuk bekerja, serta membutuhkan waktu yang lama hingga kuesioner ditinggalkan. Kondisi ini sangat mempengaruhi konsistensi responden dalam menentukan jawaban kuesioner.

Penelitian ini hanya menggunakan variabel pelatihan dan pemberdayaan untuk melihat pengaruhnya terhadap kompetensi dan kinerja guru di UPTD-PK Dewantara. 


\section{DAFTAR REFERENSI}

Baron, R. M., \& Kenny, D. A. (1986). The moderator-mediator variable distinction in social psychological research: Conceptual, strategic, and statistical

Ferdinand, Augusty. (2014). Structural Equation Modeling Dalam Penelitian Manajemen. Semarang: Badan Penerbit Universitas Diponegoro.

Ghozali, Imam. (2013). Konsep dan Aplikasi Dengan Progran AMOS 21.0. Cetakan ke 4, Badan Penerbit Universitas Diponegoro, Semarang.

Preacher, K. J. \& Leonardelli, G. J. (2001). Calculation for the Sobel test: An interactive calculation tool for mediation tests. Diakses dari http://people.ku.edu/ preacher/sobel/sobel.htm. 